Connie Angel J. Trinidad, MD'

Michael Joseph C. David, MD

Antonio H. Chua, MD ${ }^{1,2}$

'Department of Otorhinolaryngology Head and Neck Surgery

Jose R. Reyes Memorial Medical Center

2Department of Otorhinolaryngology Head and Neck Surgery

University of the East-Ramon Magsaysay

Memorial Medical Center
Correspondence: Connie Angel J. Trinidad, MD

Department of Otorhinolaryngology

Jose R. Reyes Memorial Medical Center

San Lazaro Compound, Rizal Avenue

Sta. Cruz, Manila 1003

Philippines

Phone/Fax: (632) 7436921

Reprints will not be available from the author.

No funding support was received for this study. The authors signed disclosures that they have no proprietary or financial interest with an organization that may have a direct interest in the subject matter of this manuscript, or in any product used or cited in this study.

\section{Extranasopharyngeal Angiofibroma of the Larynx}

\section{Methods:} \\ Design: Case Report \\ Setting: Tertiary Government Hospital \\ Patient: One
}

ABSTRACT

Objective: To present a rare case of laryngeal extranasopharyngeal angiofibroma, discussing its diagnosis, treatment and differences from the more typical juvenile angiofibroma.

Results: A 51-year-old male with a two-year history of hoarseness developed difficulty of breathing. Direct laryngoscopy showed a $2 \times 2 \times 1 \mathrm{~cm}$ glistening, multinodular, pedunculated, firm, pink mass attached to the posterior half of the right true vocal fold obstructing the glottic opening and extending superiorly to the ventricle. Microlaryngeal excision was done. Histopathology showing numerous vascular channels surrounded by dense paucicellular fibrous tissue was consistent with angiofibroma.

Conclusion: Primary extranasopharyngeal angiofibroma is rare, with only four previously reported cases occurring in the larynx. We presented what may possibly be the first locally reported case. Although histopathologically similar to the more common juvenile nasopharyngeal angiofibroma, this was atypically seen in the larynx of an older adult patient. Direct laryngoscopy provided excellent exposure for identification as well as complete surgical resection. Unlike the nasopharyngeal type, no massive bleeding was encountered. Prognosis for this extranasopharyngeal angiofibroma is excellent as recurrence is noted to be rare, however, long term follow-up is recommended.

Keywords: extranasopharyngeal angiofibroma, laryngeal angiofibroma

Angiofibromas typically occur in the nasopharynx. Although histologically benign, they show locally aggressive growth with bone destruction, extension to adjacent areas and possible fatal complications such as intracranial invasion or hemorrhage. Nasopharyngeal angiofibromas usually occur almost exclusively in young males and they originate at the junction of the posterolateral wall and roof of the nose at the superior margin of the sphenopalatine foramen, the approximate location of the embryological buccopharyngeal membrane and not in the nasopharynx as commonly thought.' Head and neck angiofibromas arising from outside the nasopharynx are rare. $2,3,4,5$ 


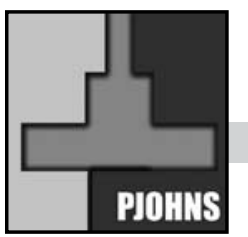

CASE REPORTS

Philippine Journal Of Otolaryngology-Head And Neck Surgery

Vol. 25 No. 1 JANUARY - JunE 2010

In a review of 65 cases of extranasopharyngeal angiofibromas (ENA), Windfuhr and Remmert found only four in the larynx. ${ }^{5}$ Clinical characteristics of ENAs do not conform with those of nasopharyngeal angiofibromas and, for this reason, these tumors must be regarded as a separate entity. ${ }^{6} \mathrm{~A}$ better understanding of this atypical entity obviates the need for unnecessary invasive procedures typically reserved for nasopharyngeal angiofibroma.

We present a case of extranasopharyngeal angiofibroma affecting the glottic region. Differences between ENA and the more typical nasopharyngeal angiofibroma will be discussed. Diagnosis and treatment of laryngeal angiofibroma will be elaborated upon.

\section{CASE REPORT}

A 51-year-old male was admitted due to progressive difficulty of breathing. He had been hoarse for two years, described as having a coarse, strained voice which gradually developed into a weak, strained voice. He was a 20-pack-year smoker and occasionally drank alcoholic beverages. Indirect laryngoscopy revealed a multinodular, non-necrotic, pink mass covering the true vocal folds and filling up the ventricles. Emergency tracheotomy was done.

Direct laryngoscopy showed a $2 \times 2 \times 1 \mathrm{~cm}$ glistening, multinodular, pedunculated, firm, pink mass attached to the posterior half of the right true vocal fold obstructing the glottic introitus and extending superiorly to the ventricle (Figure 1). Microlaryngeal excision was done with minimal bleeding that resolved spontaneously (Figure 2). Histopathological examination showed numerous vascular channels surrounded by dense paucicellular fibrous tissue (Figure 3). The cells in the fibrous tissue were cytologically bland and spindle shaped. The nuclei lacked hyperchromasia and had small nucleoili. The vascular channels were slit-like or dilated, and varied in number, configuration and thickness. Findings were consistent with angiofibroma.

While follow-up videolaryngoscopy at one week was essentially normal, a repeat three weeks post-operatively showed nodular scar tissue on the right vocal fold where the base of the excised tumor pedicle had been located (Figure 4).

\section{Discussion}

Primary extranasopharyngeal angiofibroma is very rare. ${ }^{7}$ The most common site for extranasopharyngeal angiofibroma is the maxillary sinus. The ethmoid and sphenoid sinuses, nasal septum, middle and inferior turbinate, conjunctiva, molar and retromolar region and larynx are other sites where extranasopharyngeal angiofibromas have been reported. ${ }^{8}$ Our patient may be the first locally reported case of laryngeal angiofibroma.

Angiofibroma presenting with at least one of the following criteria such as origin or location other than nasopharynx, presenting complaints other than nasal obstruction or epistaxis, age younger than seven or older than 25 , female sex and multifocality are considered

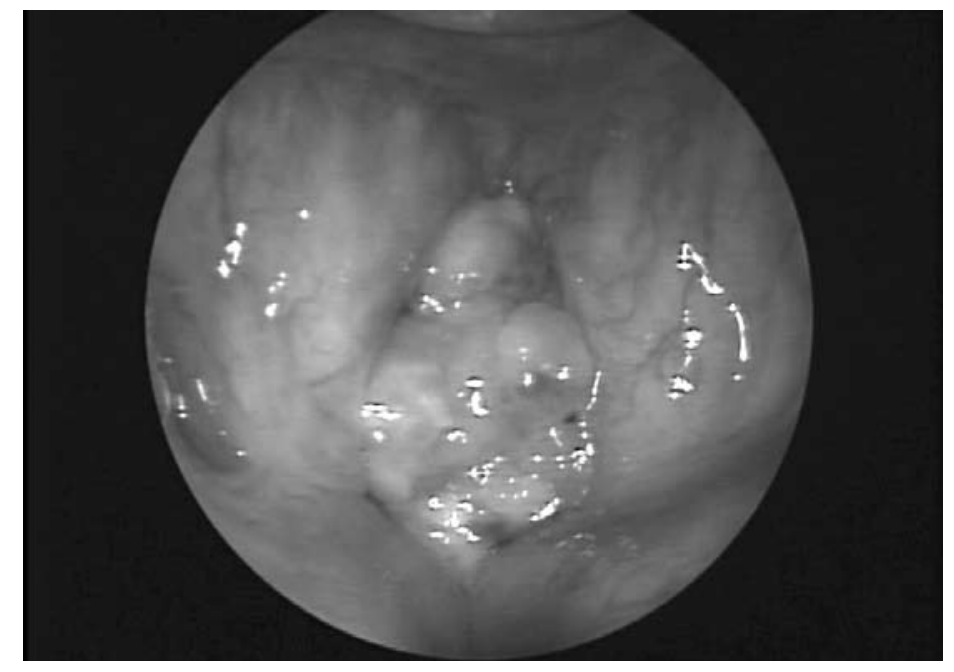

Figure 1. Glistening, multinodular, pedunculated, firm, pink mass attached to the posterior half of the right true vocal fold obstructing the glottic introitus and extending superiorly to the ventricle

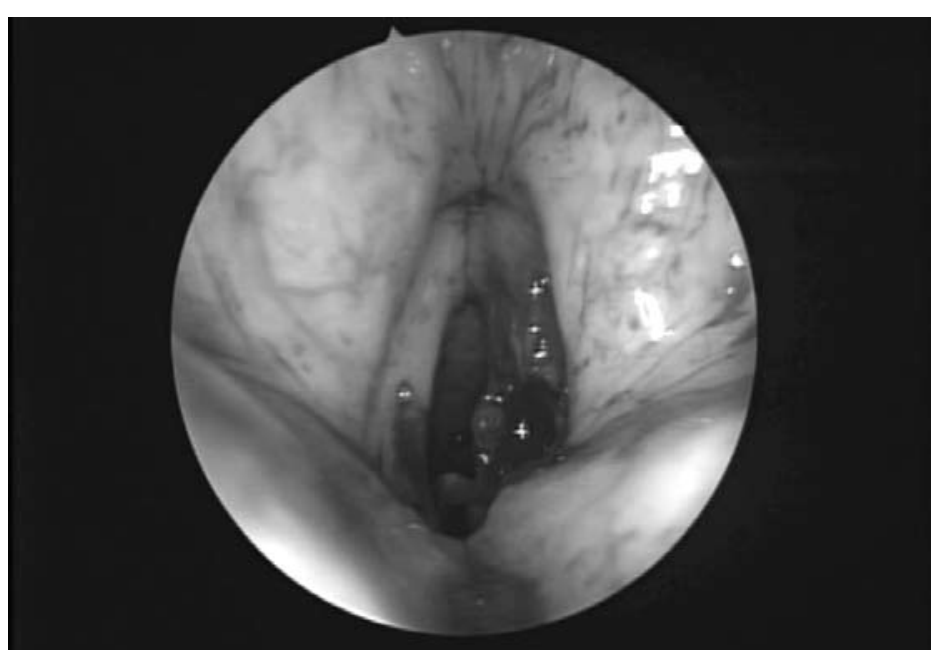

Figure 2. Larynx after excision of mass

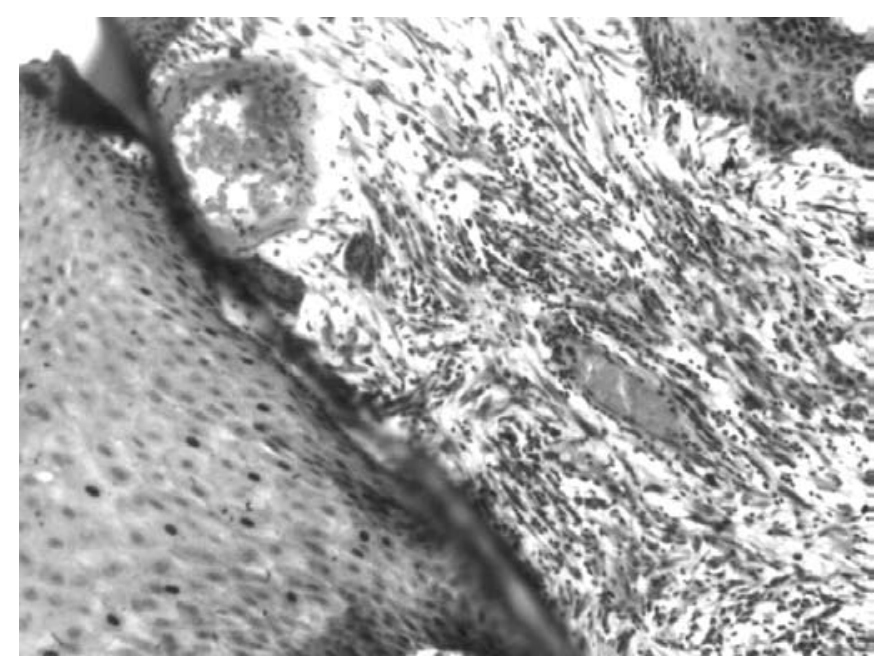

Figure 3. Microphotograph of laryngeal angiofibroma consisting of numerous vascular channels surrounded by dense paucicellular fibrous tissue 
CASE REPORTS

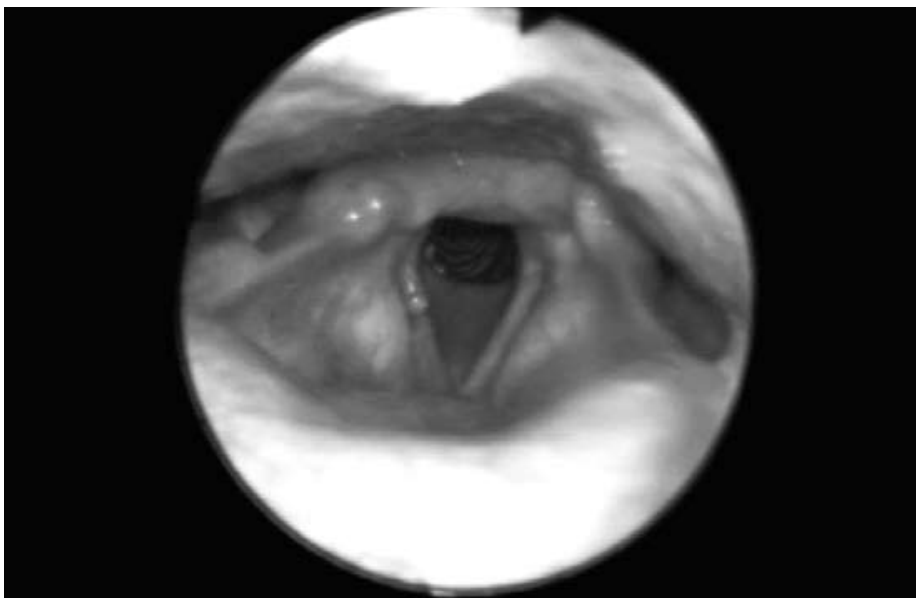

Figure 4. Videoendoscopy of Larynx, 3 weeks post-operatively Note nodular scar tissue on the right vocal fold where the base of the excised tumor pedicle had been located.

atypical. ${ }^{9}$

As benign tumors of the larynx are reported to be less than $1 \%$ of all laryngeal neoplasms, it is imperative to identify these tumors since treatment and prognosis vary greatly. ${ }^{2}$ Diagnostic modalities include computed tomography scan, magnetic resonance imaging and angiography. ${ }^{10}$ Angiofibroma of the larynx is diagnosed with direct laryngoscopy and biopsy. While biopsy of nasopharyngeal angiofibromas may not be done, it should be done in cases of laryngeal tumors to ensure that malignancies will not be missed.

Surgical excision is the treatment of choice for angiofibromas. Angiofibromas have characteristic endothelial-lined vascular spaces, with little or no smooth muscle layers and are devoid of an internal elastic lamina, which preclude vasoconstriction and contribute to brisk episodes of bleeding when traumatized. Interestingly, the feeding arteries within the stalk of the tumor mass contain a complete muscle wall which has normal contractile ability and results in little bleeding after tumor excision from its pedicle. Selective angiography has been recommended for nasopharyngeal angiofibroma as it has the ability to identify the feeding vessels and allows the option of pre-operative embolization for vascular control. ${ }^{11}$ In our case, as the mass was relatively small and easily excised at its base, minimal bleeding was encountered. It appears that angiography may not be necessary in managing laryngeal angiofibroma.

The clinical presentation of our patient (Table 1) was virtually similar to four previously reported cases. In two of the four, endolaryngeal endoscopic or microlaryngeal surgical excision was performed with successful results.,11 The two other cases involved partial laryngopharyngectomy and transcervical resection, respectively. ${ }^{5}$

Due to the confined space in the nasopharynx, inadequate surgical exposure and subsequent incomplete resection probably account for the higher recurrence rate in nasopharyngeal angiofibromas. Although tumor recurrence is rare for laryngeal angiofibromas and is not expected in our case, long-term follow-up is recommended. ${ }^{9}$
Table 1. Comparison of Reported Cases of Laryngeal Extranasopharyngeal Angiofibroma ${ }^{5,11}$

\begin{tabular}{|c|c|c|c|c|c|c|}
\hline $\begin{array}{l}\text { Case } \\
\text { No. }\end{array}$ & Age & Sex & Site & Symptom/s & Onset & Therapy \\
\hline 1 & 64 & $F$ & $\begin{array}{l}\text { Left aryepiglottic } \\
\text { area }\end{array}$ & $\begin{array}{l}\text { Dysphagia and } \\
\text { dyspnea }\end{array}$ & $2 \frac{1}{2} 2$ months & $\begin{array}{l}\text { Tracheostomy, partial } \\
\text { laryngopharyngec- } \\
\text { tomy }\end{array}$ \\
\hline 2 & 29 & M & $\begin{array}{l}\text { Right vocal fold, } \\
\text { subglottic }\end{array}$ & Hoarseness & 7 months & Microlaryngeal surgery \\
\hline 3 & 30 & $F$ & $\begin{array}{l}\text { Interarytenoid } \\
\text { region }\end{array}$ & Asymptomatic & On ORL exam & $\begin{array}{l}\text { Tracheostomy, } \\
\text { laryngofissure and } \\
\text { microlaryngeal } \\
\text { surgery }\end{array}$ \\
\hline 4 & 25 & $\bar{M}$ & $\begin{array}{l}\text { Larynx(site not } \\
\text { specified), } \\
\text { pharynx }\end{array}$ & $\begin{array}{l}\text { Dysphagia and } \\
\text { voice changes }\end{array}$ & 6 months & Transcervical resection \\
\hline $\begin{array}{l}\text { Our } \\
\text { Case }\end{array}$ & 51 & M & Right vocal fold & $\begin{array}{l}\text { Hoarseness and } \\
\text { dyspnea }\end{array}$ & 2 years & $\begin{array}{l}\text { Tracheostomy, } \\
\text { microlaryngeal } \\
\text { surgery }\end{array}$ \\
\hline
\end{tabular}

\section{REFERENCES}

1. Neel HB. Juvenile angiofibroma.In:Blitzer A, Lawson W, Friedman W, eds. Surgery at the paranasal sinuses.Philadelphia,Saunders, 1991 quoted by Gluckman JL. Tumors of the nose and paranasal sinuses.In Donald PJ, Gluckman JL, Rice DH,eds. The sinuses. New York, Raven, 1995, p.428.

2. Bastian RW. Benign mucosal and saccular disorders: benign laryngeal tumours. In: Cummings CW, Fredrickson JM, Harker LA, Krause CJ, Schuller DE, editors. Otolaryngology-Head and Neck Surgery. $2^{\text {nd }}$ ed. St. Louis: Mosby Year Book; 1993. p. 1897-1924.

3. Batsakis J. Tumours of the Head and Neck, Clinical and Pathological Considerations, 2nd ed. Baltimore: Williams and Wilkins, 1979, pp. 296-300.

4. Steele MH, Nuss DW, Faust BF. Angiofibroma of the larynx: report of a case with clinical and pathologic literature review. Head Neck. 2002 Aug; 24(8): 805-809.

5. Windfuhr JP, Remmert $S$, Extranasopharyngeal angiofibroma: etiology, incidence and management. Acta Otolaryngol. 2004 Oct; 124(8): 880-889.

6. Hunsicker RC, Koch TJ, Folander H. Superselective embolization in two cases of laryngeal paraganglioma. Otolaryngol Head Neck Surg. 1995 Jul; 113(1): 126-130.

7. Antoniades K, Antoniades DZ, Antoniades V, Juvenile angiofibroma: report of a case with intraoral presentation. Oral Surg Oral Med Oral Pathol Oral Radiol Endod. 2002 Aug; 94(2): 228232.

8. Dere H, Ozcan KM, Ergul G, Bahar S, Ozcan I, Kulacoglu S. Extranasopharyngeal angiofibroma of the cheek. J Laryngol Otol. 2006 Feb; 120(2):141-144.

9. Celik B, Erisen L, Saraydaroglu O, Coskun H. Atypical angiofibroma : A report of four cases. Int J Pediatr Otorhinolaryngol. 2005 Mar; 69(3):415-421.

10. Hsieh ST, Guo YC, Tsai TL, Chen WY, Huang JL. Angiofibroma of the hypopharynx. J Chin Med Assoc. 2004 Jul; 67(7):373-375.

11. Lim IR, Pang YT, Soh K. Juvenile angiofibroma: case report and the role of endoscopic resection. Singapore Med J. 2002 Apr; 43(4): 208-210. 